\title{
The Middle Class Is Synonymous with Corruption in Sub-Sahara Africa
}

\author{
Ishmael D. Norman 1,2*, Mark A. Aviisah', Blandina M. Awiah², Margaret Kweku', \\ Fred N. Binka ${ }^{1}$ \\ ${ }^{1}$ School of Public Health, University of Health and Allied Sciences, Ho, Ghana \\ ${ }^{2}$ Institute for Security, Disaster and Emergency Studies, Langma, Ghana \\ Email: “ishmael_norman@yahoo.com,m_aviisah_akant@yahoo.com, blandinaawiah@gmail.com, \\ margaretkweku069@gmail.com,fred.binka@gmail.com
}

Received 14 February 2016; accepted 25 April 2016; published 28 April 2016

Copyright (C) 2016 by authorsand Scientific Research Publishing Inc.

This work is licensed under the Creative Commons Attribution International License (CC BY). http://creativecommons.org/licenses/by/4.0/

c) (†) Open Access

\section{Abstract}

Objective: We investigated middle class' contribution to corruption in Sub-Sahara Africa. We assessed the effect of how the upward mobility of the middle class would be driven, if the underlying socio-economic conditions were to be improved. The third inquiry focused on whether the people appeared conflicted, where they seemed to have two separate personalities of "one for Caesar" and the "other for God" in the conduct of their official and professional duties. We finally assessed if exposure to a good dose of ethics would mitigate corrupt practices. Method: Using Ghana as the case study, we conducted a review of the literature on corruption in Sub-Sahara to assess if the phenomenon was growing with the middle class. These included published research on corruption and on the middle class in Sub-Sahara Africa. Grey literature, various government commissions' report after investigations into allegations and cases of corruption, as well as reports of the national Public Accounts Commission and those of the Controller Accountant General's available to the public on the internet was reviewed. All the findings were grouped into their respective units and the issues summarized and interpreted. Result: The middle class are the gate-keepers of policy design, implementation, monitoring and evaluation. They control service delivery and occupy middle to upper level management positions in public and private enterprises. They provide the bulk of the academic and intellectual resources and capacities for education. The effect of their conduct in professional roles may substantially contribute to the erosion of responsible moral conduct and professional ethics in the delivery of services and in the lives of the population. Discussion: The middle class is engaged in a deadly game of "catching up with the Mensahs". Whatever Mensah has, even if he acquires it illegally and through corrupt means, everyone in Mensah's neighborhood irrespective of religion, social antecedents and professional ethics, wants to be just like Mensah. Conclusion: Such conduct does not consider the moral and legal duty of care of the

\footnotetext{
"Corresponding author.
}

How to cite this paper: Norman, I. D., Aviisah, M. A., Awiah, B. M., Kweku, M., \& Binka, F. N. (2016). The Middle Class Is Synonymous with Corruption in Sub-Sahara Africa. Advances in Applied Sociology, 6, 179-198. 
middle class to the population guided by ethical principles.

Keywords

Corruption, Middle Class Role, Ghana, Sub-Saharan Africa

\section{Introduction}

Frantz Fanon's 1961 book, “The Wretched of the Earth” called the African middle class the bourgeoisies. Fanon described the membership of the bourgeoisies to include the rent-seeking, kleptomaniac government officials and the pretentious do-gooders. That is to say the entities engaged in the private-public-partnerships, whose pre-occupation, he argued,(is) how best they could enrich themselves through a large network of friends, classmates, and acquaintances. Corruption (the misuse of public office for private gain) in Sub-Saharan Africa is a major socio-economic burden on the population, particularly in high government (Ugaz, 2015). It is found among the middle classes and officialdom, (Norman \& Aviisah, 2015; Norman et al., 2014; Le, de Haan, \& Dietzenbacher, 2013; Soreide et al., 2012; Van Rijckeghem \& Weder, 2001; Abbink, 2000; Abbink et al., 2002; Klitgaard, 1998). It is a difficult burden to get rid of (Agbodohu \& Quarmyne, 2014). It is a hindrance to development (United Nations Sustainable Development Goals, 2015; DFID, 2012; Gockel, 1995; Agbodeka, 1992; Frimpong-Ansah, 1991; Fosu, 1989; Ewusi, 1987), a definite threat to democracy and good governance (Bond, 2006). It has negative implications even on healthcare delivery (Di Tella et al., 2001; Di Tella et al., 2003). Corruption as a social virus disease is ubiquitous and insidious (Norman \& Aviisah, 2015; Norman et al., 2014; Le, de Haan, \& Dietzenbacher, 2013; Søreide et al., 2012; Van Rijckeghem \& Weder, 2001; Abbink, 2000; Abbink et al., 2002; Klitgaard, 1998).

Most nations in the world have incidences of corruption but in the case of Sub-Saharan Africa, institutional and official corruption appears more systemic and intransigent (United Nations Sustainable Development Goals, 2015; Ugaz, 2015; Agbodohu \& Quarmyne, 2014; Gockel, 1995). Describing how Ghana has surpassed Nigeria regarding the perception of corruption in each country by the nationals, and trailing behind South Africa, Transparency International (TI) reports that, "corruption has created and increased poverty and exclusion”. It adds that "while corrupt individuals with political power enjoy a lavish life, millions of Africans are deprived of their basic needs like food, health, education, housing, access to clean water and sanitation” (Ugaz, 2015). The perpetrators of corruption are unabashed about how they display the ill-gotten fruits of their official malfeasance in their private lives (Criminal Offences Act, 1960: pp. 124-125). In Ghana and in many Sub-Saharan African nations, the perpetrators of corruption engage in many public and private activities which eventually become known by an appreciable number of people in their immediate circles. Such activities include chasing and keeping several women as concubines, buying expensive vehicles, buying properties in gated real estate communities, going on foreign vacations with their concubines and gigolos, drinking high priced alcoholic beverages, and wasting large parts of the bounty on short-lived but fanciful ends. It is a bourgeoisie lifestyle that is difficult to understand and explain, particularly in the face of abject poverty. The same so-called sophisticated urbanchampagne consuming class men and women continue to have linkages to their ancestral homes in the rural areas, where poverty is most biting without empathy or sympathy for their kinsmen. In the case of Nigeria, a vast majority of its 140 million populations live below the poverty line. Yet, the lifestyles of some well placed individuals and their families in the urban centers are a source of great worry. This is because they display shameless conspicuous consumptive habits with money they have not, perhaps, honestly earned (Abbink, 2000). For example, in 2010, Nigeria boosted as one of the strongest markets for luxury champagnes such as Dom Pérignon, Moet etChandon Brut, Moet et Chandon Nectar, Veuve Clicquot, Duval-Leroy and Laurent Perrier (Nigeria's Thirst for Champagne, 2010). "Nigeria spends an average of N41.41 billion on champagne yearly and is rated as the second fastest growing market in the world for champagne". Although this claim is doubtful, it is still significant. In a research conducted by Euromonitor International, between 2006 and 2011, Nigeria achieved a compound annual growth of 22 percent in champagne consumption. Total champagne consumption reached 752,879 bottles (75 cl) in 2011, higher than consumption in Russia and Mexico; therefore, placing Nigeria among the top 20 champagne markets in the world. In 2010, Nigeria consumed about 593,000 bottles, the 
highest consumption in Africa. The closest to this figure was South Africa, another country that has been identified as an emerging market for luxury goods, in addition to Nigeria. South Africa's champagne consumption was 384,000 bottles in 2010" (Nigeria Sun News, 2015). Drinking champagne is not in and itself, a social negative. The conduct has its utility and celebrative place in the affairs of people. What may attract indignation is how the habit is financed.

Researchers such as Ugaz (2015); Abbink (2000); Norman and Aviisah (2015); Norman et al. (2014); Le, de Haan, \& Dietzenbacher (2013); Lindner (2013); Soreide et al. (2012); Bond (2006); Di Tella et al. (2001); Di Tella et al. (2003); Van Rijckeghem \& Weder (2001); Abbink et al. (2002); Agbodohu \& Quarmyne (2014); Gockel (1995); Agbodeka (1992); Frimpong-Ansah (1991); Fosu (1989); Ewusi (1987) and Klitgaard (1998) all agree that corruption has increased despite increases in salaries.

The question is who is responsible for the perceived or real exponential growth in corruption in Africa as a whole? We need to find out who does what in the apportionment of responsibility, not blame, in this massive economic hemorrhagic bleeding of billions of dollars a year for private ends. These activities are perpetrated by often economically and politically well placed individuals in the respective African economies.

\section{Alibi for the Colonials and Surrogates}

There was a time when finding the perpetrator of perceived generic public harm was a no brainer. This was because in the era gone-by, it was politically correct to cast blame on the so-called Africa's colonial masters for the woes of Africa in general and in South Africa and Namibia on Apartheid policy in specific. That convenient culprit of the past is no longer available. Time and space have given convincing alibis to the colonials and their surrogates, multinational corporations as the perpetrators, the enemies of progress in Africa. It is, therefore, not palatable to blame the colonial masters for the chronic under-development and worsening of economic growth in the respective African nations. Fanon (1961) reported that "the national middle class that took over power at the end of the colonial regime was an under-developed middle class. It had practically no economic power, and in any case it was in no way commensurate with the bourgeoisie of the mother country which it hoped to replace..." He added that "the national bourgeoisie of under-developed countries was not engaged in production, nor in invention, nor building, nor labor", but rather "canalized into activities of the intermediary type. Its innermost vocation seems to be to keep in the running and to be part of the racket".

By the racket, Fanon saw the colonialists as a cartel organized illegally for the exploitation of the weak, the uneducated and the vulnerable colonial peoples of that era. The colonialists were the enemies of the colonial people everywhere. Today the enemies of progress in Africa have been modified by time, space and autonomy to be the Africans themselves. The African middle class form the cartels that run the racket, by deduction from Fanon's, 1961 exposition. These are the emerging and growing middle class, the political leadership, the intellectual classes, adult men and women over the age of majority, the bureaucracy, the bankers, the professors, the teachers, and the rank and file of the security forces, the clergy and the laity. The list is exhaustive. The "racket" appears to be so good that others want to join; it seems (AfDB, 2011).

In the "Rise and Rise of the Middle Class" Deloitte researchers for the African Development Bank provided that "as a percentage of the population, the middle class has been steadily rising. Prior to the 1980's it represented over 111 million or $26 \%$ of the Continent's population inclusive of floaters. This figure fell due to exogenous economic shocks and stresses of the decade (AfDB, 2011). Some of these shocks and stresses were a series of coup d'états in Sub-Saharan Africa between 1978 and 1989. These developments were inconsistent with good governance (Norman \& Aviisah, 2015). The coup planners justified their usurpation of power on the basis of the deterioration of the fortunes of the populations (Aryeetey, 1996; Carlson \& Putnam, 1993; Blanchard et al., 1996; Bluwey, 1998).

To help arrest what appeared as persistent bad governance, over-blown national deficit budget and financing, coupled with a general sense of doom, the World Bank with the IMF introduced an economic bandage that came to be called the Structural Adjustment Program. It was reasoned that the fundamental national fiscal and economic structure were catastrophically fractured (Agbodohu \& Quarmyne 2014). The seemingly never ending World Bank and IMF inspired Structural Adjustment Programs and other economic burdens placed on African economies and their populations a great deal of stresses.

But by 1990's and despite the noticeable economic hardships, the middle class had risen to 151.4 million of the population or $27 \%$. It surged to 196 million in 2000 with a dramatic rise to 313 million in 2010 or $34.3 \%$ of 
the Continent's total population (African Development Bank, 2011). This represents a growth rate of 3.1\% in the middle class population over the period 1980 to 2010, compared with a growth rate of $2.6 \%$ in the continent's overall population over the same period (Ncube et al., 2011).

Even within the middle class cohort, there is further segmentation into upper-middle, middle-middle and lower-middle classes, which is determined by wealth and other antecedents such as education and income levels (Banerjee \& Duflo, 2008; Easterly, 2001; Kharas \& Gertz, 2010; Visagie, 2013; Visagie \& Posel, 2013; Wilson \& Dragusanu, 2008). For example whereas “Botswana's middle class were at the upper limit with $48 \%$ of its population classified as middle class, Gabon was at the lower limit of the next category of the classification with $75 \%$ of its population classified as middle class. Algeria was the next nation to show upward trend with respect to the overall growth of the middle class with 77\%, Egypt with $80 \%$, Morocco having $85 \%$ and Tunisia 90\%" (AfDB, 2011; Villasenor \& Arnold, 1989; Kakwani, 1980; Ravallion \& Huppi, 1991; Datt, 1998; World Wealth Report, 2009; Lynch, 2009).

\section{Defining the Middle Class, Middle Class Role in Development and in Corruption}

We have decided to focus the investigations into the middle class in their various configurations since they tend to constitute the bulk of the bureaucracy, the majority of the university teachers as well as the bank workers and the accountants, to mention but a few trades and professions. Fanon (1961) had argued that the middle class of the newly independent nations were essentially a liability on the affairs and progress of these respective nations. We wanted to assess whether Fanon's assertion about the middleclass in Ghana was true. We had assumed that the middle class was more than a liability, but rather part of the machinery contributing to national development. Though we did not specifically assess Fanon's hypothesis, we selected this particular class of the population in order to understand it better. It is to assess their role in economic development and to appreciate their attributes in relation to nation building.

Writing for the African Development Bank, Ncube et al. (2011) ventured that the middle class is a concept that can be defined in relative or absolute terms. In relative terms, the middle class is defined as individuals or households that fall between the 20th and 80th percentile of the consumption distribution or between 0.75 and 1.25 times median per capita income, respectively (Birdsall et al., 2000; Bhalla, 2009; Banarjee \& Duflo, 2007). Using the absolute approach, the middle class is usually defined as individuals with annual income exceeding $\$ 3900$ in purchasing power parity (PPP) terms or with daily per capita expenditure between $\$ 2$ to $\$ 4$ and those with daily per capita expenditures between $\$ 6$ and \$10 (Ramachandran, 2009; Ravallion, Chen, \& Sangraula, 2008). This definition offers a wide range of segments of middle class. In terms of wellbeing, it seems it is purely subjective and therefore prone to biases and prejudicial description. It appears the African middle class differs in many respects from the middle class in the Western Industrial nations where anyone with an income of less than USD $\$ 25,000.00$ would be considered as lower class person. Visagie (2013) in attempting to define who the middle class is in South Africa and using data from 2008, described the middle class as being "synonymous with both the affluent and the very affluent..." But Visagie also posed if "such an affluence-based conceptualization of the middle class was sensible or relevant to policy making in South Africa?" The option Visagie chose was one which defines the middle class as households which fall within a specified income interval. This is because of the differences in the size of households and the number of mouths to feed. That is to say, to determine per capita income, one needed to divide the household income by the household size. The second way of assessing the middle class is to choose an interval of per capita household income that indicates some conception of relative affluence, which is often associated with certain patterns of expenditure and possessions (AfDB, 2011; Easterly, 2001, 2007 cited in Visagie, 2013). For the rest of Sub-Sahara Africa, there appears to be no collective concern for a common methodology for the calculation of the middle class status of the populations. Researchers and scholars use different approaches so long as it fits the hypothesis they may be trying to affirm or rebut.

In certain sections of the United States of America; such as Connecticut, per capita income was approximately USD \$ 48,700.00 between 2009 and 2013. At the same time, the median household income was USD\$82,200.00 for 2009 to 2013 (Dept of Numbers, Connecticut, 2009). Generally the middle class in the Western industrialized nations tend to be captains of industry and lead the entrepreneurial push such as in Germany and elsewhere and do the exact opposite of what Fanon described about the African middle class as not doing in 1961.

Banerjee \& Duflo (2008) stated that what separates the "middle class" (which they define as living on between \$2 and \$10 per day) from the poor in developing countries are steady well-paying jobs, not greater suc- 
cess at running small businesses. The African middle class tends to be salaried worker and not particularly able to do much in terms of investment compared to their western counterparts. We offer in Figure 1, the characteristics of the African Middle Class.

\section{Procedure}

The research did not concern itself with empirical research such as a cross-sectional study to assess incidence and prevalence of corruption perpetrated by the middle class. The authors assumed that the middle class provide the human and other resources to the national economy. They, the middle classes form the strongest cohort of consumers and drive many of the national agendas. Therefore, it was more useful to this exercise to test the effects of their roles in either perpetuating corrupt practices or sustaining such practices once they are set in motion. The middle classes form the majority of the bureaucracy, the policy formulators and implementers. If there is a problem with the system over which the middle class; by and large; oversee it is the middle class to which attention should be focused. Considering the persistent outbreak of common diseases such as cholera and malaria that are all but eradicated in many technologically advanced nations, it is hard to comprehend that there is a wealthy class in Sub-Saharan Africa (Global Malaria Program, WHO, 2009; D’Acremont et al., 2009). But they are present, engaged in activities such as banking, building materials fabrication and manufacturing, pharmaceutical development and a long list of economic activities. The wealthy class men and women are often not engaged in public services, but in private investment activities, where accountability and best business practices are often in place. Despite this observation, the wealthy class men and women are also susceptible to corruption. They may participate in the social vice either as inducers or facilitators and "influencers" of corrupt activities (Ncube et al., 2011). As for the marginalized majority low class men and women, their role in sustaining any kind of social conduct would be limited by their lack of purchasing power and actual lack of access to power and connections.

\section{Inclusion and Exclusion Criteria for the Assessment of Effects}

We adopted strict inclusion criteria for the papers we reviewed for this article. We also searched through newspapers for the period to assess reports of corrupt activities on embezzlement, misappropriation and other nefarious financial activities conducted by the professional classes and the emerging middle class men and women. We found (87) Eighty-seven publications that met the inclusion criteria out of over 200,000 articles, opinions, blogs, grey literature and policy documents. Twenty-seven (27) of the articles were not specifically on the middle class but on corruption in general in various aspects of public life as seen in Table A in Appendix. We assigned an overall score and identified the position taken in the publication or report in relation to the objectives. We scored: 1 = Entirely Relevant (ER); 1/2 = Somewhat Relevant (SR); and 0 = Not Relevant at All, (NRaA) against descriptors such as (i) focused on question, (ii) literature review, (iii) depth of argument on corruption/middle class or ethics, (iv) overall conclusion. We rated them and the papers that received scores above

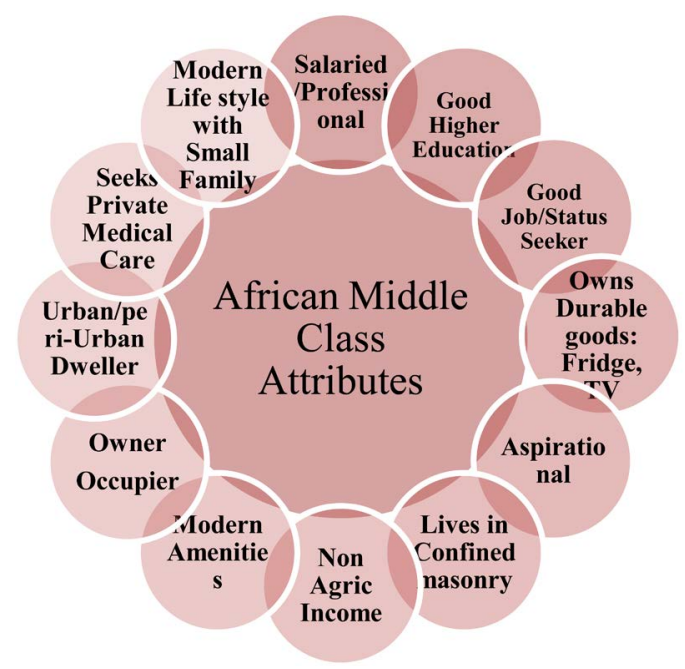

Figure 1. Characteristics of the African middle class. 
2.5 out of 4 in this evaluation were further analyzed. We summarized the findings into their respective units, and interpreted them based upon our skills, knowledge and specialization in ethics, policy, sociology, public health and law. The authors excluded papers and reports that addressed day-to-day middle class lifestyles, investment activities and crimes including petty crimes or even extreme crimes such as murder. Authors did not conduct epidemiological investigation into the incidence and frequency of both financial and official corruption. Papers that dealt with ethics particularly those that did not address capacity, responsibility, autonomy, respect, and beneficence on the national or international level were not included.

We tested and assessed the following effects:

1) The effect of the middle classes on official corruption;

2) The effect of the middle classes on corruption assuming good ethical education;

3) Effect of the middle classes on corruption assuming the absence of peer-pressure;

4) Effects of culture of sycophancy and blind support of thieving kinsmen.

We also searched the internet and other data bases such as Google Scholar and Hunari, including journals on management and economics for information, case studies and other research on the issue with carefully designed search combinations. The data was disaggregated into the respective themes for analyses and summarized the findings into their respective units, and interpreted them based upon the authors' skills, knowledge and specialization in policy and management and in public health in general.

\section{Outcomes of Theoretical Investigation and Discussion}

\section{1) The effect of the middle classes on official corruption}

What is the effect of the middle classes on corruption if the middle classes move to the wealthy classes and do no longer desire to be part of the racket of corrupt officials or government functionaries? Assuming the underlying economic conditions are improved, the nation moves from being a poor nation to a middle income nation, would the quantum of mundane corruption come down or would it rather go up? Foltz \& Opoku-Agyemang (2015) examined the data on 2100 long-haul journeys plying between Ghana and Burkina Faso. They found that “... Ghana's police became more corrupt after their salaries increased, both absolutely and relative to Burkina Faso's police and Ghanaian customs officers. The cops erected more roadblocks, detained Lorries for longer (the average driver was stopped 16 times as he drove through Ghana, for eight minutes each time) and extracted more money..."

There appears to be anecdotal evidence in the literature suggesting that corruption in general would be minimized over time, when the underlying macro- and micro-economic policies are improved across board (Abbink, 2000; Lindner, 2013; Chêne, 2009; Mahmood, 2005; Mtonya \& Chizimbi, 2006; Norman \& Aviisah, 2015; Norman et al., 2014; Agbodohu \& Quarmyne, 2014). There is however no evidence so far identified in the literature to suggest that when the middle classes move to the upper class wealth quintile, somehow that would lead to a behaviour modification and mitigate their attraction to corruption (Ugaz, 2015; Public Accounts Committee, 2014; Ghana Controller’s General, 2013; Killick, 2010; Klitgaard, 1998). In fact and consistent with the finding of Foltz \& Opoku-Agyemang (2015) the very people caught in the quagmire of massive corruption across many nations in Sub-Sahara Africa are those who are already wealthy and not just rich. They are most connected in each nation and have access that goes all the way to the very seat of government and power. Even when the fundamentals of the nations improve, there ought to be simultaneous improvement in the judiciary services and general justice administration as well as in criminology and penology. Many of the perpetrators of massive corruption in the respective nations know they can get away with murder, so to speak and often they do (Foltz \& Opoku-Agyeman, 2015; Lindner, 2013; Abbink et al., 2012; Abbink, 2000; Ul-Haque et al., 1996). For example, a former Ghana's Attorney General authorized that a local business man sympathetic to her political leanings, be paid the cedi equivalent of $€ 22,129,501.74$ for his alleged financial engineering costs alone, without ascertaining whether the claim by the contractor were valid or not in 2015. The authorization for the payment and the payment amount were subsequently found by the Ghana Supreme Court to be illegal and must be refunded to the national exchequer (GH, MOFEP, 2015).

In Kenya and beginning from the 1990's through a greater part of 2000's, the Goldenburg Scandal involving the dissipation of about USD \$600 from the national exchequer and involving officials in Arap Moi's and Mwai Kibaki's governments occupied the attention of both donors and nationals for a long time.

In Nigeria, it has been reported that 60 million barrels of oil valued at $\$ 13.7$ bn was stolen under the watch of the national oil giant, Nigerian National Petroleum Corporation from 2009 to 2012 (NNPC, 2016). 


\section{2) The effect of the middle classes on corruption assuming good ethical education}

What would be the effect on corruption if the population was well versed in ethical precepts of responsibility, beneficence, non-malfeasance, and truth-telling and therefore enjoyed high moral fitness as a society? Responsibility here is used as a synonym for duty of care. Beneficence simply means that whatever duty that is owned to the population by the public official should be exercised to benefit the public good. Non-malfeasance as a biomedical ethical value can be explained in the context of public service and the public good to mean the collective efforts and industry of the middle class or professional class should not cause any harm to the population, but should enrich their lives. Truth-telling demands that in the rendition of government policy, in the operationalization of national programs, in the delivery of public services, the public official or agent should be in a position to disclose to the public at large identifiable mistakes, unintended commissions and omissions, even negligence that causes material harm or financial loss to the state. The official or agent should then, after disclosure put in place corrective measures so as to return the public to the status it would have been but for the commission, omission, or negligence.

Whether or not the corrupt practices of the population would be modified positively if the population is given a good dose of exposure to ethics remains to be tested and assessed. This, however, implies the mainstreaming of education in ethics as the sine quo non for mitigating corruption in Ghana or in any of the nations in Sub-Saharan Africa. The issue of mainstreaming ethics as part of the mundane aspects of the lives and behaviors of the population of Sub-Saharan Africa is novel and unproven as a social intervention. The average Sub-Saharan African person is steeped in either the religious ethics of Islam or Christianity. In the last decade, in Ghana for example, there has been a large influx of neighborhood churches, erection of multiplicity of bigger church edifices. Religion in general has become the new Small Scale Enterprises, the new growth industry in the face of dwindling manufacturing base (Norman, 2013). If despite the prestige of these world religions the corrupt egoist (who is incidentally either a Muslim or Christian), still engages in nefarious financial crimes, then teaching such a person secular ethical conduct and behavior would have an overall marginal or zero effect on behavior (Norman \& Aviisah, 2015). Ethics as a subject matter is contextual, situational and modified by culture and politics, although there are basic universal ethical standards that applies to all nations similarly situated, such as the ethico-legal prohibition against human trafficking or Female Genital Mutilation. At the parochial community level, "the nation has not taken the time to design the parameters for finding solutions to the complex problem of working with the morality of the indigenous populations. Morality in the metropolis may differ and do differ from that which is displayed by those in the more parochial environment. The nation has also not developed ethical code for the conduct of research specific to the traditional members of the Ghanaian society and their engagement with outside partners (Norman \& Aviisah, 2015; Castellano, 2004; Norman, Aikins, \& Binka, 2010; Buchanan, 2008; Castellano, 2004; Beauchamp \& Childress, 2001).

Despite the foregoing, it is not difficult to gauge how exposure to ethical principles which the population internalizes into their conduct would not lead to behavior modification among the population. That said, in Sub-Sahara Africa, ethical principles such as autonomy, choice, and informed consent are not operationalized in exactly the same way that it is applied in the Western Industrialized nations (Buchanan 2008; Gostin, 2005; Emanuel \& Emanuel, 1992). The family unit takes precedence over communal and societal interests (Sivalingam, 2011). Therefore, even concepts such as autonomy, choice, and informed consent are viewed from the family's point of view than from that of the individual. The choice making ability, autonomy and the capacity to make informed decision are influenced, sometimes to a fault, by the family, the spouse, mostly the men and the financiers of the individual with the capacity. This phenomenon is observed even among urban, more metropolitan inhabitants who do not maintain day-to-day contact with the broader, bigger family unit in the rural areas or in one's village (Norman et al., 2014; Sivalingam, 2011). In this respect, the ethical values of responsibility, respect, and beneficence resonates more aptly with the Sub-Saharan Africa's cultural hierarchy and power dynamics between the old and young, between wives and husbands, and between the rich and poor (Buchanan, 2008; Beauchamp \& Childress, 2001; Norman, Aikins, \& Binka, 2010; Castellano, 2004). Finally, religion has been found to moderate certain negative conduct including corruption or addiction (Beita, 2008; Durham Jr., 2008; Feldman, 2005; Cochran et al., 2004; Brothers, 1993; Burton, 1992; Butler \& Harper, 1994; Carter, 1993; Prest \& Keller, 1993; Berman, 1983). Even though the Ghanaian identifies first with the family before the nation, it appears religious affiliation is insidiously replacing the family for determining one's belonging identity. Some researchers argue that religion is rather being used more as a tool for social networking, personal advancement and eminence, rather than as a means to spiritual fulfillment (Norman, 2014). Although religion plays very in- 
fluential role among the members of a particular group, it appears what pertains is nothing more than elevated religiosity (McFarland, Uecker, \& Regnerus, 2011; Brothers, 1993; Burton, 1992; Butler \& Harper, 1994; Prest \& Keller, 1993; Beita, 2008; Durham Jr., 2008; Feldman, 2005; Cochran et al., 2004; Carter, 1993; Berman, 1983). Elevated religiosity is defined as Church attendance and strength of religious identification (McFarland, Uecker, \& Regnerus 2011).

\section{3) Effect of the middle classes on corruption assuming the absence of peer-pressure}

Measuring the effect of the middle classes on corruption in the absence of peer pressure is the same as assessing the effect of the culture of sycophancy and blind support of thieving kinsmen. We will therefore treat both effects as if they were one. It is important to accept that the Ghanaian culture does not admonish or condemn relatives who every member of the family knows or suspects to be stealing from his or her employer or the government. Although there may be the occasional caution of a member of the family to the perpetrator, there is hardly ever a situation where the concerned family remember would report the suspicion even covertly, no matter how strong it may be, to the police for investigations. Spouses and children of men and women in positions of power who engage in systematic plunging of the national or official coffers are aware or suspect their spouses or parents to be thieving from their jobs, but do nothing or turn a blind eye to such activities. There are religious leaders, who suspect certain members of their congregation to be actively stealing from their employers or know for a fact that they are stealing through confessions and other conversations. Yet, the culture does not have the moral capacity to shun such persons, admonish them or even expose them (Foltz \& Opoku-Agyemang, 2015; Van Rijckeghem \& Weder, 2001; Abbink et al., 2002; Jacobsen \& Abdolkarim, 1996). The culture accommodates such characters and protects from exposure. The opinion leaders ensure that such wrong doers are protected in order to gain monetary and other benefits from such personalities. Is the cultural idiosyncrasy of not punishing wrong doing the reason for corruption among the middle class? What would be the effect on corruption if the population did not appear to be conflicted, where they seem to have two separate personalities of "one for Caesar" and the "other for God" in the conduct of their official and professional duties? Is the culture of keeping up with their neighbors the reasons for corruption? Would sustained public education on patriotism and the adverse consequences of corruption of the middle classes against aping their neighbors the solution to the reduction of corruption within the professional lives of the middle classes? There appears to be more questions than one research paper can handle. Most of these inquiries are raised for other researchers to test and assess. Sub-Sahara Africa has had the opportunity of military leadership and lived under dictatorial regimes that provided draconian and harsh punishments to those who erred or found to have been corrupted. During all of such period, Sub-Sahara Africa became more entrenched in corrupt practices and rent-seeking behaviors than ever before (Norman \& Aviisah, 2015).

\section{Conclusion}

The middle class is blame-worthy when their direct or indirect role in the deterioration of the economic fortunes of Sub-Sahara Africa is considered. They are the gate-keepers, the architects of monetary and other policies; they develop the templates for official conduct. They are the key players in policy formulation, operationalization, monitoring and evaluation of programs coming out of policies; they are the master accountants, bankers, lawyers, investment advisors, and auditors as well as accountable professions. Yet they see to the hemorrhaging, the plunging and outright stealing of the national and international liquidity of the respective nations. They help to invent the procurement mechanism that actually costs the nations more to purchase through the procurement mechanism than not. They craft the rules of engagement for what is punishable and what is not, because they are the judges, the lawyers, the top brass of the police and other quasi law enforcement organizations, they alone should be blamed for corruption in their respective nations. The middle class in Sub-Sahara Africa manages to delude themselves and the rest of their people that there is no class system in their nations. Because of that, they attack and organized forces, both local and international on moral and humanitarian grounds, against the Boa apartheid regime in South Africa. Whiles condemning the racist regime of South Africa, they run and manage cities that practiced exclusion in places like Accra, Ghana in the case of slum settlement like "Sodom and Gomorrah"; otherwise known as Old Fadama. In Nairobi, Kenya, the famous Kibera slum is created to show the duality of behavior of the Kenyan middle class: condemn apartheid and embrace economic segregation nationally. The middle class lifestyles and creed led to the uprising in Nigeria in the Niger Delta in the late 1980's and throughout the 1990s and segued into a more virulent form of social protester: Boko Haram. If Sub-Sahara 
Africa has a future to contend with, that future, that oracle ought to be divined by the middle class by looking inward into itself and bringing an end to systemic extreme financial corruption in Sub-Sahara Africa. In our modern globalized world, everything is related to everything else (Lorenz, 1972).

\section{References}

Abbink, K. (2000). Fair Salaries and the Moral Costs of Corruption. Bonn Econ Discussion Papers, No. 1/2000.

Abbink, K., Irlenbusch, B., \& Renner, E. (2002). An Experimental Bribery Game. Journal of Law, Economics, and Organization, 18, 428-454. http://dx.doi.org/10.1093/jleo/18.2.428

Agbodeka, F. (1992). An Economic History of Ghana: From the Earliest Times. Accra: Ghana Universities Press.

Agbodohu, W., \& Quarmyne, R. C. (2014). Corruption in Ghana: Causes, Consequences and Cures. International Journal of Economics, Finance and Management Sciences, 2, 92-102. http://dx.doi.org/10.11648/j.ijefm.20140201.20

Aryeetey, E. (1996). Structural Adjustment and Aid in Ghana. Friedrich Ebert Foundation, Ghana Office.

Aryeetey, E., \& Kanbur, S. M. R. (2007). The Economy of Ghana: Analytical Perspectives on Stability, Growth \& Poverty. Oxford: James Currey.

Banerjee, A. V., \& Duflo, E. (2008). What Is Middle Class about the Middle Classes around the World? Journal of Economic Perspectives, 22, 3-28. http://dx.doi.org/10.1257/jep.22.2.3

Beauchamp, T. L., \& Childress, J. F. (2001). Principles of Biomedical Ethics (5th ed.). Oxford: Oxford University Press.

Beita, P. B. (2008). French President’s Religious Mixing of Riles Critics. Christianity Today.

Berman, H. J. (1983). Law and Revolution. The Formation of the Western Legal Tradition. Cambridge, MA: Harvard University Press.

Bhalla, S. (2009). The Middle Class Kingdoms of India and China. Washington DC: Peterson Institute for International Economics.

Birdsall, N., Graham, C., \& Pettinato, S. (2000). Stuck in Tunnel: Is Globalization Muddling the Middle Class? Center on Social and Economic Dynamics WP, 14, 36.

Blanchard, E. B., Jones-Alexander, J., Buckley, T. C. et al. (1996). Psychometric Properties of the PTSD Checklist (PCL). Behaviour Research and Therapy, 34, 669-673. http://dx.doi.org/10.1016/0005-7967(96)00033-2

Bluwey, G. K. (1998). State Organizations in the Transition to Constitutional Democracy. In K. A. Ninsin (Ed.), Ghana: Transition to Democracy (pp. 167-185). Accra: Freedom Publications.

Bond, P. (2006). Persistent Court Corruption. The Economic Journal, 118, 1333-1353. http://onlinelibrary.wiley.com/doi/10.1111/j.1468-0297.2008.02172.x/epdf?r3_referer=wol\&tracking_action=preview_cli ck\&show checkout=1\&purchase referrer=onlinelibrary.wiley.com\&purchase site license=LICENSE DENIED http://dx.doi.org/10.1111/j.1468-0297.2008.02172.x

Braddock III, C. H., Edwards, K. A., Hasenberg, N. M., Laidley, T. L., \& Levinson, W. (1999). Informed Decision Making in Outpatient Practice: Time to Get Back to Basics. Journal of the American Medical Association, 282, 2313-2320.

http://dx.doi.org/10.1001/jama.282.24.2313

Braddock, C. H., Fihn, S. D., Levinson, W., Jonsen, A. R., \& Pearlman, R. A. (1997). How Doctors and Patients Discuss Routine Clinical Decisions: Informed Decision-Making in the Outpatient Setting. Journal of General Internal Medicine, 12, 339-345.

Bradt, D. A. (2009). Evidence-Based Decision-Making in Humanitarian Assistance. Humanitarian Practice Network, Overseas Development Institute, No. 67, December 2009, 1-24.

Brothers, B. J. (Ed.) (1993). Spirituality and Couples: Heart and Soul in the Therapy Process. New York: Haworth Press.

Buchanan, D. R. (2008). Autonomy, Paternalism, and Justice: Ethical Priorities in Public Health. American Journal of Public Health, 98, 15-21.

Burton, L. A. (1992). Religion and the Family. New York: Haworth Press.

Butler, M. A., \& Harper, J. M. (1994). The Divine Triangle: God in the Marital System of Religious Couples. Family Process, 33, 277-286.

Carlson, E. B., \& Putnam, F. W. (1993). An Update on the Dissociative Experiences Scale. Dissociation, 6, 16-27.

Carter, S. L. (1993). The Culture of Disbelief: How American Law and Politics Trivialize Religious Devotion. New York: Basic Books, 328 p. (Book Review by Monsma, S. V. (2008) Journal of Church and State, 22, 6) http://www.highbean.com/doc/1G1-188155499.html

Castellano, M. B. (2004). Ethics of Aboriginal Research. Journal of Aboriginal Health, 1, 98-114.

Chêne, M. (2009). Low Salaries, the Culture of Per Diems and Corruption. U4 Expert Answer. 
http://www.u4.no/helpdesk/helpdesk/query.cfm?id=220

Cochran, J. K., Chamlin, M. B., Beeghley, L., \& Fenwick, M. (2004). Religion, Religiosity, and Nonmarital Sexual Conduct: An Application of Reference Group Theory. Sociological Inquiry, 74, 70-101. http://dx.doi.org/10.1111/j.1475-682X.2004.00081.x

D’Acremont, V., Lengeler, C., Mshinda, H., Mtasiwa, D., Tanner, M., \& Genton, B. (2009). Time to Move from Presumptive Malaria Treatment to Laboratory-Confirmed Diagnosis and Treatment in African Children With fever. PLoS Medicine, 6, e252. http://dx.doi.org/10.1371/journal.pmed.0050252

Datt, G., \& Ravallion, M. (1998). Why Have Some Indian States Done Better than Others at Reducing Rural Poverty? Economica, 65, 17-38. http://dx.doi.org/10.1111/1468-0335.00112

Department for International Development (DFID) (2012). Impact Assessment of the Zimbabwe Health Worker Retention Scheme.

https://www.gov.uk/government/uploads/system/uploads/attachment_data/file/213900/Impact-assess-zimb-health-workers -retention-schemeFinal_20Report_20.pdf

Di Tella, R., \& Savedoff, W. D. (Eds.) (2001). Diagnosis Corruption: Fraud in Latin America's Public Hospitals. Washington DC: Inter American Development Bank.

http://www.iadb.org/en/research-and-data/publicationdetails,3169.html?pub_id=b-133f

Di Tella, R., \& Schargrodsky, E. (2003). The Role of Wages and Auditing during a Crackdown on Corruption in the City of Buenos Aires. The Journal of Law \& Economics, 46, 269-292.

http://citeseerx.ist.psu.edu/viewdoc/download?doi=10.1.1.373.1682\&rep=rep1\&type=pdf http://dx.doi.org/10.1086/345578

Durham Jr., C. W. (2008). State and Religion in America: Problems and Perspective. Provo, UT: Brigham Young University Law Library. http://www.iclrs.org/10/4/2011

Easterly, W. (2001). The Middle Class Consensus and Economic Development. Journal of Economic Growth, 6, $317-335$. http://dx.doi.org/10.1023/A:1012786330095

Easterly, W. (2007). Inequality Does Cause Underdevelopment: Insights from a New Instrument. Journal of Development Economics, 84, 755-76. http://dx.doi.org/10.1016/j.jdeveco.2006.11.002

Emanuel, E. J., \& Emanuel, L. L. (1992). Four Models of the Physician-Patient Relationship. JAMA, 267, 2221-2226. http://dx.doi.org/10.1001/jama.1992.03480160079038

Ewusi, K. (1987). Structural Adjustment and Stabilization Policies in Developing Countries: A Case study of Ghana's Experience in 1983-1986. Tema: GPC.

Fanon, F. (1961). The Pitfalls of National Consciousness, Chapter 3. The Wretched of the Earth. https://www.marxists.org/subject/africa/fanon/pitfalls-national.htm

Feldman, N. (2005). Divided by God. New York: Farrar, Straus and Giroux.

Foltz, J. D., \& Opoku-Agyemang, K. A. (2015). Do Higher Salaries Lower Petty Corruption? A Policy Experiment on West Africa's Highways? Madison, WI: University of Wisconsin-Madison, Department of Agricultural and Applied Economics.

Fosu, K. Y. (1989). Agriculture in Ghana's Post-1970 Development Process. 5th Biennial Conference of the West African Economic Association, Lome, November, Togo.

Frimpong-Ansah, J. H. (1991). The Vampire State in Africa: The Political Economy of Decline in Ghana. Africa World Press.

Ghana Controller’s and Accountant General Report (2013). http://www.ghana.gov.gh

Ghana Public Accounts Committee Report (2014). http://www.ghana.gov.gh

Global Malaria Program, World Health Organization (2009). Malaria Case Management: Operations Manual. Geneva: WHO.

Gockel, A. F. (1995). The Role of Finance in Economic Development: The Case of Ghana. An Unpublished Ph.D. Thesis, Manchester: University of Manchester.

Gostin, L. O. (2005). Jacobson v Massachusetts at 100 Years: Police Power and Civil Liberties in Tension. American Journal of Public Health, 95, 576-581. http://dx.doi.org/10.2105/AJPH.2004.055152

Jacobsen, E., \&Sadrieh, A. (1996). Experimental Proof for the Motivational Importance of Reciprocity (No. 386). Bonn: University of Bonn.

Kakwani, N. (1980). On a Class of Poverty Measures. Econometrica, 48, 437-446. http://dx.doi.org/10.2307/1911106

Kharas, H., \& Gertz, G. (2010). The new global middle class: a cross-over from West to East (1-14). Wolfensohn Center for Development at Brookings.

Killick, T. (2010). Development Economics in Action: A Study of Economic Policies in Ghana (2nd ed). London: Routledge. 
Klitgaard, R. (1998). International Cooperation against Corruption. Finance \& Development, 35. https://www.imf.org/external/Pubs/FT/fandd/1998/03/pdf/klitgaar.pdf

Le, V., de Haan, J., \& Dietzenbacher, E. (2013). Do Higher Government Wages Reduce Corruption? Evidence Based on a Novel Dataset. CESIFO Working Paper No. 4254.

http://www.cesifogroup.de/portal/page/portal/DocBase_Content/WP/WPCESifo_Working_Papers/wp-cesifo-2013/wp-ces ifo-2013-05/cesifo1_wp4254.pdf

Lindner, S. (2013). Salary Top-Ups and Their Impact on Corruption. Bergen, Norway: U4 Anti-Corruption Resource Centre.

Lorenz, E. N. (1972). Predictability: Does the Flap of a Butterfly's Wings in Brazil Set off a Tornado in Texas. American Association for the Advancement of Science.

http://gymportalen.dk/sites/lru.dk/files/lru/132_kap6_lorenz_artikel_the_butterfly_effect.pdf

Lynch, M. (2009). Capgemini (2006): World Wealth Report 2006. World Wealth Report 2009, New York: Merrill Lynch.

Mahajan, V. (2009). Africa Rising: How 900 Million African Consumers Offer More than You Think. New York: Pearson Education, Inc.

McFarland, M. J., Uecker, J. E., \& Regnerus, M. D. (2011). The Role of Religion in Shaping Sexual Frequency and Satisfaction: Evidence from Married and Unmarried Older Adults. The Journal of Sex Research, 48, 297-308. http://dx.doi.org/10.1080/00224491003739993

Mtonya, B., \& Chizimbi, S. (2006). System Wide Effects of the Global Fund in Malawi: Final Report. Bethesda, MD: The Partners for Health Reform plus Project, Abt Associates Inc.

Ncube, M., Lufumba, C. L., \& Steve, K. (2011). The Middle of the Pyramid: Dynamics of the Middle Class in Africa. Market Brief, 20 April 2011, African Development Bank.

Norman, I. D. (2013). Separation of Church and State: A Study of Accra City’s Use of Public Buildings and Schools for Religious Services in Ghana. Advances in Applied Sociology, 3, 282-288. http://dx.doi.org/10.4236/aasoci.2013.37036

Norman, I. D., \& Aviisah, M. A. (2015). Does Corruption Manifest Post Traumatic Stress Disorder? Donnish Journal of Neuroscience and Behavioral Health, 1, 12-20. http://www.donnishjournals.org/djnbh

Norman, I. D., Aikins, M., \& Binka, F. N. (2010). Sexual Harassment and Health among the Immigration, Police and Fire Services of Ghana. Pilot Study. Unpublished, Legon, Accra: School of Public Health, College of Health Sciences, University of Ghana.

Norman, I., Awiah, B. M., Aikins, M. K., \& Binka, F. N. (2014). The Review of Ghana’s Legislative Preparedness to Critical National Risks: Terrorism and Money Laundering. Issues in Business Management and Economics, 2, 201-209. http://journalissues.org/wp-content/uploads/2014/12/Norman-et-al.pdf

Prest, L. A., \& Keller, J. F. (1993). Spirituality and Family Therapy: Spirital Beliefs, Myths, and Metaphors. Journal of Marital and Family Therapy, 19, 137-148. http://dx.doi.org/10.1111/j.1752-0606.1993.tb00973.x

Ramachandran, V., Gelb, A., \& Shah, M. K. (2009). Africa's Private Sector: What's Wrong with the Business Environment and What to Do about It. Center for Global Development.

Ravallion, M., \& Huppi, M. (1991). Measuring Changes in Poverty: A Methodological Case Study of Indonesia during an Adjustment Period. The World Bank Economic Review, 5, 57-82. http://dx.doi.org/10.1093/wber/5.1.57

Ravallion, M., Chen, S., \& Sangraula, P. (2008). Dollar a Day Revisited. Policy Research Working Paper 4620, Washington DC: World Bank.

Sivalingam, N. (2011). Medical Paternalism and Patient Autonomy; the Dualism Doctors Contend with. The Medical Journal of Malaysia, 66, 421-422.

Søreide, T., Tostensen, A., \& Skage, I. A. (2012). Hunting for Per Diem: The Uses and Abuses of Travel Compensation in Three Developing Countries. Norwegian Agency for Development Cooperation (NORAD).

Ugaz (2015). Corruption in Africa: 75 Million People Pay Bribes.

Ul-Haque, N., \& Sahay, R. (1996). Do Government Wage Cuts Close Budget Deficits? Costs of Corruption. International Monetary Fund Staff Papers, 43, 754-778. http://dx.doi.org/10.2307/3867368

UN Open Working Group of the General Assembly on Sustainable Development Goals Is Issued as Document A/68/970 (2015). http://undocs.org/A/68/970

Department of Numbers (2009). Connecticut's per Capita Income. http://www.deptofnumbers.com/income/connecticut/

Van Rijckeghem, C., \& Weder, B. (2001). Bureaucratic Corruption and the Rate of Temptation: Do Wages in the Civil Service Affect Corruption, and by How Much? Journal of Development Economics 65, 307-331.

http://www.sciencedirect.com/science/article/pii/S0304387801001390

Villasenor, J., \& Arnold, B. C. (1989). Elliptical Lorenz Curves. Journal of Econometrics, 40, 327-338. http://dx.doi.org/10.1016/0304-4076(89)90089-4 
Visagie, J. (2013). Race, Gender and Growth of the Affluent Middle Class in Post-Apartheid South Africa. In Biennial Conference of the Economic Society of South Africa, Bloemfontein: University of the Free State.

http://www.econrsa.org/system/files/publications/working_papers/working_paper_395.pdf

Visagie, J., \& Posel, D. (2013). A Reconsideration of What and Who Is Middle Class in South Africa. Development Southern Africa, 30, 149-167. http://dx.doi.org/10.1080/0376835X.2013.797224

Wilson, D., \& Dragusanu, R. (2008). The Expanding Middle Class: The Exploding World Middle Class and Falling Global Inequality. Goldman Sachs Economic Research Global Economics Papers Issue 170, New York: Goldman Sachs. 


\section{Appendix}

Table A. Critical analysis of papers on the role of the middle class' contribution to corruption.

\begin{tabular}{|c|c|c|c|c|c|c|c|}
\hline No. & Source & $\begin{array}{c}\text { Focused } \\
\text { on } \\
\text { Question }\end{array}$ & $\begin{array}{l}\text { Literature } \\
\text { Search }\end{array}$ & $\begin{array}{l}\text { Corruption } \\
\text { Middle } \\
\text { Class/Ethics } \\
\text { Argument }\end{array}$ & Conclusion & $\begin{array}{l}\text { Total } \\
\text { Score }\end{array}$ & Summary of Position \\
\hline 1 & Agbodeka, F. (1992) & 1 & 1 & 1 & 1 & 4 & $\begin{array}{l}\text { Corruption in SSA has had } \\
\text { negative effect on economy }\end{array}$ \\
\hline 2 & Agbodohu \& Quarmye (2004) & 1 & 1 & 1 & 1 & 4 & Ditto \\
\hline 3 & Ewusi, K. (1987) & $1 / 2$ & $1 / 2$ & 1 & 1 & 3 & $\begin{array}{l}\text { Corruption affects economic } \\
\text { malaise }\end{array}$ \\
\hline 4 & Fosu, L. Y. (1989) & $1 / 2$ & 1 & $1 / 2$ & $1 / 2$ & $21 / 2$ & Ditto \\
\hline 5 & Visagie, J. (2011) & $1 / 2$ & 1 & $1 / 2$ & $1 / 2$ & $21 / 2$ & $\begin{array}{l}\text { Marginal growth in size and } \\
\text { income levels of the middle } \\
\text { class results in marginal } \\
\text { economic development. }\end{array}$ \\
\hline 6 & $\begin{array}{l}\text { Kharas, H., \& Gertz, G. (2010). The } \\
\text { new global middle class: a cross-over } \\
\text { from West to East. Wolfensohn Center } \\
\text { for Development at Brookings, 1-14. }\end{array}$ & $1 / 2$ & $1 / 2$ & 1 & $1 / 2$ & $21 / 2$ & $\begin{array}{l}\text { Growth in the middle class } \\
\text { translates into increased } \\
\text { expenditure, incomes, and } \\
\text { economic advancement. }\end{array}$ \\
\hline 7 & $\begin{array}{l}\text { Visagie, J., \& Posel, D. (2013). A } \\
\text { reconsideration of what and who is } \\
\text { middle class in South Africa. } \\
\text { Development Southern Africa, 30(2), } \\
\text { 149-167. } \\
\text { http://doi.org/10.1080/0376835X.2013. } \\
\underline{797224}\end{array}$ & 1 & 1 & 1 & $1 / 2$ & $31 / 2$ & $\begin{array}{l}\text { The middle class serves as a } \\
\text { proxy measure for changes } \\
\text { in income inequality and } \\
\text { economic development. }\end{array}$ \\
\hline 8 & $\begin{array}{l}\text { Visagie, J., \& others (2013). Race, } \\
\text { gender and growth of the affluent } \\
\text { middle class in post-apartheid south } \\
\text { Africa. In at Biennial Conference of the } \\
\text { Economic Society of South Africa, } \\
\text { University of the Free state, } \\
\text { Bloemfontein. Retrieved from } \\
\text { http://www.econrsa.org/system/files/pu } \\
\text { blications/working_papers/working_pa } \\
\text { per_395.pdf }\end{array}$ & 1 & 1 & 1 & $1 / 2$ & $31 / 2$ & $\begin{array}{l}\text { Overall growth of the } \\
\text { middle class results in an } \\
\text { improvement in economic } \\
\text { fortunes of the populace. }\end{array}$ \\
\hline 9 & $\begin{array}{l}\text { Easterly, W. (2001). The middle class } \\
\text { consensus and economic development. } \\
\text { Journal of Economic Growth, 6(4), } \\
\text { 317-335. }\end{array}$ & 1 & $1 / 2$ & 1 & 1 & $31 / 2$ & $\begin{array}{l}\text { A higher share of income for } \\
\text { a middle class that is less } \\
\text { ethnically divided translates } \\
\text { into growth and } \\
\text { development. }\end{array}$ \\
\hline 10 & $\begin{array}{l}\text { Cochran, J.K., Chamlin, M.B., } \\
\text { Beeghley, L., \& Fenwick, M. (2004). } \\
\text { Religion, religiosity, and nonmarital } \\
\text { sexual conduct: an application of } \\
\text { reference group theory. Sociological } \\
\text { Inquiry, 74(1), 70-101. }\end{array}$ & $1 / 2$ & 1 & $1 / 2$ & $1 / 2$ & $21 / 2$ & $\begin{array}{l}\text { Exposure to religious } \\
\text { teaching and ethics reduces } \\
\text { desire to engage undesirable } \\
\text { conduct such as corruption. }\end{array}$ \\
\hline 11 & $\begin{array}{l}\text { Banerjee, A. V., \& Duflo, E. (2008). } \\
\text { What is middle class about the middle } \\
\text { classes around the world? Journal of } \\
\text { Economic Perspectives, 22(2), 3-28. } \\
\text { http://doi.org/10.1257/jep.22.2.3 }\end{array}$ & 1 & 1 & 1 & 1 & 4 & $\begin{array}{l}\text { Countries that have a larger } \\
\text { middle class grow faster. }\end{array}$ \\
\hline 12 & $\begin{array}{l}\text { Aryeetey, E., \& Kanbur, S. M. R. } \\
\text { (2007). The economy of Ghana: } \\
\text { analytical perspectives on stability, } \\
\text { growth \& poverty. Oxford: James } \\
\text { Currey. }\end{array}$ & $1 / 2$ & 1 & $1 / 2$ & 1 & 3 & $\begin{array}{l}\text { Corruption by civil servants, } \\
\text { customs officials and } \\
\text { policemen } \\
\text { enormously increases the } \\
\text { transaction cost for all } \\
\text { economic endeavors in } \\
\text { Ghana. }\end{array}$ \\
\hline
\end{tabular}




\section{Continued}

13 Klitgaard, R. (1998). International 1 cooperation against corruption. Finance \& Development, 35(1). Retrieved from http://209.133.61.144/external/Pubs/FT /fandd/1998/03/pdf/klitgaar.pdf

14 Mauro, P. (1998). Corruption: causes, consequences, and agenda for further research. Finance and Development, 35, 11-14.

15 Fanon (1961) $1 / 2$ $1 / 2$

6 Braddock, C. H., Fihn, S. D., Levinson, 1/2 W., Jonsen, A. R. and Pearlman, R. A. (1997). How doctors and patients discuss routine clinical decisions: informed decision-making in the outpatient setting. Journal of General Internal Medicine, 12 (6): 339-345.

17 Mauro, P. (1995). Corruption and growth

18 Easterly, W., \& Ross, L. (1997). "Africa’s growth tragedy: policies and ethnic divisions.”

19 John Mukum Mbaku (2010). Corruption in Africa: causes, consequences and cleanups.

20 Burton, L. A. (ed.) (1992). Religion and the family. New York: Haworth Press

21 Durham Jr., C. W. (2008). State and religion in America: problems and perspective.; Brigham Young University Law Library, Provo, Utah http://www.iclrs.org/10/4/2011

22 Feldman, N. (2005). Divided by God. 1/2 Farrar, Straus and Giroux.

23 Beita, P. B. (2008). French President's 1/2 religious mixing riles critics. Christianity Today.

24 Graham, C., Birdsall, N., \& Pettinato, 1 S. (2000). Stuck in the Tunnel: Is Globalisation Muddling the Middle Class? Centre on Social and Economic Dynamics WP, 14, 36.

$1 / 2$

$1 / 2$

1

$1 / 2$

1

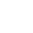

12




\section{Continued}

25 Norman, I., Awiah, B. M., Aikins, M. K., \& Binka, F. N. (2014). The review of Ghana's legislative preparedness to critical national risks: Terrorism and money laundering. Retrieved from http://journalissues.org/wp-content/upl oads/2014/12/Norman-et-al.pdf

Hull, L., David, A. S., Hyams, K. C., Unwin, C., Wessely, S. C., \& Hotopf, M. (2002). Self-reported health Persian Gulf War veterans: a comparison of help-seeking and randomly ascertained cases. Military Medicine 167 (9): 747-752.

27 Huq, M. M. (1989). The economy of 1 Ghana: The first 25 years since independence. St. Martin’s Press.

28 Hutchful, E. (2002). “Ghana’s adjustment experience: the paradox of reform”, United Nations Research Institute for Social Development, Geneva, Switzerland.

29 ISSER, (1995). State of the Ghanaian economy in 1994. Published by Institute of Statistical, Social and Economic Research (ISSER), University of Ghana, Legon.

30 UN Open Working Group of the General Assembly on Sustainable Development Goals is issued as document $\mathrm{A} / 68 / 970$, (http://undocs.org/A/68/970) 2015

31 Easterly, W. (2007). Inequality does 1 cause underdevelopment: insights from a new instrument. Journal of Development Economics, 84: 755-776.

32 Beauchamp, T. L., \& Childress, J.F. (2001). Principles of biomedical Ethics. 5th Ed. Oxford University Press.
Levinson, W. (1999). Informed

decision making in outpatient practice: time to get back to basics. Journal of the American Medical Association 282 (December 22/29, 1999): 2313-20.
$31 / 2 \quad$ Ethical values are not operationalized exactly in SSA as by western industrialized nations.

$21 / 2$ Citizens in SSA who engage in corruption possess different characteristics (perhaps have been less exposed to ethical education) from those who do not. Therefore those who engage in corrupt practices are unrepresentative of the entire citizenry. This mimics a population with conflicted personalities in the discharge of their professional duties.

3 1/2 Rent seeking by middle class citizens has had deteriorating consequences on the national economy.

$31 / 2 \quad$ Ditto

3 1/2 The cumulative effect of over two decades of fiscal indiscipline and rent seeking in the public sector has stagnated economic growth.

3 Rent seeking behavior and corruption of the middle class in SSA militates against the desire to reach "The future we want" devoid of injustice, inequity and economic exclusion.

$31 / 2 \quad$ Corruption sustained by the middle class in SSA begets inequality which does cause underdevelopment.

$31 / 2$ Ethical values such as responsibility, non-malfeasance, respect, and beneficence are not operationalized exactly as in western nations in SSA. Family interest takes precedence over communal or societal interests.

$21 / 2$ Strategies to make corrupt practices a disincentive to citizens yield positive outcomes. 


\section{Continued}

34 Buchanan, D. R. Autonomy, Paternalism, and Justice: ethical priorities in public health. Am J Public Health. 2008 January; 98(1): 15-21. doi: 10.2105/AJPH.2007.110361PMCID: PMC2156058

35 Castellano Marlene B. Ethics of Aboriginal Research. Journal of Aboriginal Health, 2004; 1(1): 98-114.
$1 \quad 1 / 2$

1

$1 / 2$

$1 / 2$

3

Ethical principles such as autonomy, paternalism and justice are not operationalized in SSA exactly as in western societies. Most incidences of corruption originate from unethical behavior.

SSA nations have not developed ethical codes specific to their cultural and traditional settings with members of society and engagement with outside partners.

36 Wilson, D. and Dragusanu, R. (2008). 1 anding middle class: the exploding world middle class and falling global inequality. Goldman Sachs Economic Research Global Economics Papers Issue 170. Goldman Sachs: New York.

37 Mahajan, V. (2009), Africa rising: how 1 900 million African consumers offer more than you think. Pearson Education, Inc.

38 Ramachandran, V. A. Gelb, and M. K. 1 Shah (2009). Africa's private sector: what's wrong with the business environment and what to do about it.

39 Ravallion, M., S. Chen and P. Sangraula (2008). Dollar a day revisited. Policy Research Working Paper 4620, World Bank, Washington, DC.

40 Villasenor, J., \& Arnold, B. C. (1989). Elliptical lorenz curves. Journal of Econometrics, 40(2), 327-338. 1989.

41 Kakwani, N. (1980). On a class of poverty measures. Econometrica: Journal of the Econometric Society, 437-446. Kakwani 1980.

42 Ravallion, M., \&Huppi, M. (1991). 1 Measuring changes in poverty: a methodological case study of Indonesia during an adjustment period. The World Bank Economic Review, 5(1), 57-82.Ravallion and Huppi 1990.

43 Datt, G., \& Ravallion, M. (1998). Why 1 have some Indian states done better than others at reducing rural poverty? Economica, 65(257), 17-38. Datt 1998.

44 Lynch, M. (2009). Capgemini (2006): 1 World Wealth Report 2006. New York. World Wealth Report 2009, Merrill Lynch.
A growing middle class results in a decrease in inequality in SSA.

Growth in size of the middle class in SSA has economic benefits.

Private sector development upward mobility of the middle class in SSA.

Growth in size of the middle class in SSA indicates a reduction in poverty and inequality.

Categories of middle class status indicate progressive economic growth and inequality gap in SSA.

Ditto

Categories of middle class status indicate progressive economic growth and reduction in the income inequality gap in SSA.

Economic growth and human development necessary for poverty reduction (growth of middle class) in SSA. different rates. and growth causes an reduction in the income 


\section{Continued}

45 Killick, T. (2000). "Fragile Still? The Economy of Ghana, 1960-94” in Economic Reforms in Ghana, Miracle or Mirage. (eds). Aryeetey, E., J.

Harrigan and M. Nissanke, Oxford, James Currey and Accra, Woeli Publishers. economics in action: a study of economic policies in Ghana (2. ed). London: Routledge.

47 Mansfield, C. (1980). "Tax Base Erosion and Inflation: The Case of Ghana”, in Finance and Development, September 1980, page 34.

48 Lorenz EN. 1972. Predictability: Does the flap of a butterfly's wings in Brazil set off a tornado in Texas. American Association for the Advancement of Science. http://www.chaostheory.

$49 \quad$ Ncube et al. (2011)

$50 \quad$ Norman and Aviisah (2015)

51 Gockel, A. F. (1995). The role of finance in economic development: the case of Ghana. An unpublished $\mathrm{PhD}$ Thesis, University of Manchester, U.K.

52 Frimpong-Ansah (1991)

53 Ugaz, 2015 Corruption in Africa: 75 million people pay bribes.

54 Ghana Public Accounts Committee report, 2014.

55 Ghana Controller's and Accountant General Report, 2013

56 Sivalingam, N. (2011). Medical paternalism and patient autonomy; the dualism doctors contend with. Medical Journal of Malaysia, 66(5), 421-422.

57 Brothers, 1993
$1 / 2$

1

$1 / 2$

$1 / 2$

1

1

1

1

$1 / 2$

$1 / 2$
$1 / 2$

(a)

3 Rent seeking in the public sector in Ghana contributes to economic malaise.

2 1/2 Perverse economic policies, political instability and fiscal indiscipline in the public sector deepened Ghana's economic woes.

2 1/2 Economic mismanagement in public sector leads to deteriorating living conditions.

$21 / 2$ In a globalized world corruption by the middle class in SSA sets off a vicious cycle of deteriorating economic fortunes, inequality, poverty and instability.

4 Human capital development in SSA would lead to the growth and rise of the middle class amidst economic prosperity.

4 The root cause of corruption in the SSA could be traced to economic shocks and stresses exacerbated by political instabilities over time.

$21 / 2$ Economic growth is essential for development and growth of the middle class.

2 1/2 Political economy factors affect economic growth.

4 Corruption affects the quality of life of the ordinary citizens in SSA: imposes extreme economic burden.

$31 / 2$ Corruption is a disincentive to Ghana's development.

$31 / 2$ Corruption is a burgeoning phenomenon in Ghana's public sector.

3 The ethical principle of individual autonomy is sidestepped by family autonomy in some societies in SSA.

$21 / 2$ Exposure to religious teaching and ethics reduces desire to engage in undesirable behavior such as corruption. 


\section{Continued}

58 Prest, L. A., \& Keller, J. F. (1993). Spirituality and family therapy: spirital beliefs, myths, and metaphors. Journal of Marital and Family Therapy, 19(2), 137-148.

59 McFarland, M. J., Uecker, J. E., \& Regnerus, M. D. (2011). The role of religion in shaping sexual frequency and satisfaction: evidence from married and unmarried older adults. Journal of Sex Research. 2011.

60 Norman, I. D. (2013). separation of church and state: a study of accra city's use of public buildings and schools for religious services in Ghana. Advances in Applied Sociology, 3(07), 282.

61 Carter, S. L. (1993). The culture of disbelief: how american law and politics trivialize religious devotion. New York: Basic Books, 328.

62 Berman, H. J. (1983). Law and revolution. The formation of the western legal tradition. Harvard: Harvard University Press.

63 U.S District Court, S. D., New York, v. Lebanese Canadian Bank SAL, Ellissa Holding Company, Hassan Ayash Exchange Company, Cybamar Swiss GMBH, LLC Ste, 2011.

64 Luna DM (2008). Narco-Trafficking: What is the Nexus with the War on Terror? Anticrime Programs, Bureau of International Narcotics and Law Enforcement Affairs. U. S. Dept of State: http://merln.ndu.edu/archivepdf/terroris m/state/110828.pdf 22/1/12

66 Gostin, L. O. (2005). Jacobson v Massachusetts at 100 years: police power and civil liberties in tension. American Journal of Public Health, 95(4), 576-581.

67 Emanuel, E. J., \& Emanuel, L. L. (1992). Four models of the physician-patient relationship. Jama, 267(16), 2221-2226.

68 Norman, I. D., Aikins, M., \& Binka, F. N. (2010). Sexual harassment and health among the immigration, police and fire services of Ghana. Pilot study. Unpublished, School of Public Health, College of Health Sciences, University of Ghana, Legon, Accra, Ghana.

69 Bradt, D. A. (2009). Evidence-Based Decision-Making in Humanitarian Assistance. Humanitarian Practice Network, Overseas Development Institute. No.:67, December 2009: 1-24.
$21 / 2 \quad$ Spiritual belief system/ethical edification is a possible alternative for curtailing undesirable behavior such as corruption.

$21 / 2$ Religiosity has positive influence on achieving desirable outcomes.

Ghanaians appear to have conflicted personalities: "one for Caesar and the other for God”.

Despite elevated religiosity, religion can moderate negative conduct such as corruption.

Religion has a positive impact on the legal system: a revolution.

International corruption and money laundering is possible due to corrupt officials who are supposed to control such activities

Drug trafficking, money laundering and financing of terrorism potentially have their solutions in the introduction of ethical standards in the public workers and increase general accountability.

Ethical principles by government to safeguard public health are not operationalized in SSA as in developed nations.

The informative model for bioethical principles such as paternalism and autonomy is dominant in industrialized nations than in SSA.

Ghana has not developed ethical codes specific to the cultural and traditional settings with members of society and engagement with outside partners.

Public health ethics are not operationalized in SSA as in other developed parts of the world. 


\section{Continued}

70 Burton, L. A. (1992). Religion and the family. New York: Haworth Press.

71 Butler, M. A., \& Harper, J. M. (1994). The divine triangle: God in the marital system of religious couples. Family Process, 33, 277-286.

http://dx.doi.org/10.1111/j.1545-5300.1 994.00277.x

72 Bhalla, S. (2009). The Middle Class Kingdoms of India and China. Peterson Institute for International Economics, Washington, DC.

74 Ul-Haque, Nadeem, and Ratna Sahay (1996): Do Government Wage Cuts Close Budget Deficits? Costs of Corruption. International Monetary Fund Staff Papers, 43:4, 754-778.

75 Bond, P. (2006). "Persistent court corruption.” Economic Journal 118, 1333-1353. http://finance.wharton.upenn.edu/ pbo $\underline{\text { nd/research/ms2004460r.pdf }}$

76 Chêne, M. (2009). "Low salaries, the culture of per diems and corruption”, U4 Expert Answer. http://www.u4.no/publications/low-sala ries-the-culture-of-perdiems-and-corrup tion/

76 Department for International Development (DFID). 2012. Impact assessment of the Zimbabwe Health Worker

Retention Scheme.

https://www.gov.uk/government/upload s/system/uploads/attachment data/file/ 213900/Impact-assess-zimb-healthwork ers-retention-schemeFinal_20Report_2 $\underline{0 . p d f}$

77 Di Tella, R. and Savedoff, W.D., eds. 2001. Diagnosis corruption: Fraud in Latin America's public hospitals. Inter American Development Bank:

Washington, DC.

http://www.iadb.org/en/research-and-da ta/publicationdetails3169.html?pub id= b-133f

Di Tella, R., Schargrodsky, E. 2003.

"The role of wages and auditing during a crackdown on corruption in the city ofBuenos Aires.” Journal of Law \& Economics 46, 269-292.

http://www.lacea.org/meeting2000/Raf aelDiTella2.PDF
Religion is replacing the family as an important means of identity.

Religion has a positive impact on negative conduct such as corruption.

The rise of the middle class propels national economies.

An increase in wages alone does not reduce corruption in the public sector.

Larger court penalties necessitate higher corruption; Paying court officials wages sufficiently above the market-clearing rate can eliminate the high corruption equilibrium but not corruption.

Low government wages in developing countries result in a decline of public sector efficiency and productivity and create incentives and opportunities for corruption, brain drain, and misuse of public resources.

Corruption in the public service erodes resources forservice improvement and development.

Corruption is a critical obstacle to social development, well-functioning democratic institutions, and economic progress in developing countries' public sector.

Higher-than market clearing wages alone is insufficient to deter corruption in the public sector. 


\section{Continued}

78 Le, V., de Haan, J. and Dietzenbacher, E. 2013.” Do higher

government wages reduce corruption? Evidence based on a novel dataset." CESIFO Working Paper No. 4254. http://www.cesifogroup.de/portal/page/ portal/DocBase_Content/WP/WPCESif o_Working_Papers/wp-cesifo-2013/wp -cesifo-2013-05/cesifo1_wp4254.pdf

79 Mahmood, M. 2005. "Corruption in civil administration:

Causes and cures." Humanomics no 21 (3/4): 62-84.

80 Mtonya, B. Chizimbi, S. 2006.

"Systemwide effects of the

Global Fund in Malawi: Final report.” Bethesda, MD: The

Partners for Health Reform plus

Project, Abt Associates Inc.

81 Søreide, T., Tostensen, A., \& Skage, I A. (2012). Hunting for per diem: the uses and abuses of travel compensation in three developing countries. Norwegian agency for development cooperation (Norad).

82 Van Rijckeghem, C., Weder, B. (2001). "Bureaucratic corruption and the rate of temptation: do wages in the civilservice affect corruption, and by how much?" Journal of

Development Economics 65, 307-331.

http://www.sciencedirect.com/science/a rticle/B6VBV-4384R2T-5/2/7cf1f9a26 d8c910dda8478d078c39c83

83 Abbink, Klaus (2000). Fair Salaries and the Moral Costs of Corruption, Bonn Econ Discussion Papers, No. $1 / 2000$

84 Lindner, S. (2013). Salary top-ups and their impact on corruption. Bergen, Norway: U4 Anti-corruption Resource Centre.

85 Abbink, K., Irlenbusch, B., \& Renner, E. (2002). An experimental bribery game. Journal of Law, Economics, and Organization, 18(2), 428-454.

86 Foltz, J. D., \& Opoku-Agyemang, K. A. (2015). Do higher salaries lower petty corruption? A policy experiment on west africa's highways1.

87 Jacobsen, E., \& Sadrieh, A. (1996). Experimental proof for the motivational importance of reciprocity (No. 386). University of Bonn, Ger\#many.
Theimpact of government

wages on

corruption is

strong at relatively

low-income levels.

Proffers that a proper balancing of the pay structure, power, and accountability mechanism might combat corruption in the public sector.

Corruption in the public service erodes resources for service improvement and development.

Misuse or non-optimal use of money is a usual occurrence by public officials in developing countries.

A rather large increase in wages is required to eradicate corruption solely by raising wages in low income countries. However, in order to achieve that large of an increment, the increase has to be so huge that it is not sustainable in actual or absolute terms.

Increases in salaries do not reduce corruption in the public sector.

Increasing salaries in the public sector is not sufficient for reducing corruption.

Experimental table top game to assess the effect increased remuneration. Corruption is not reduced in the face of increasing salaries among public sector workers.

Higher salaries does not stop petty corruption among the Police in Ghana who are engaged in traffic control.

Society's "accommodation" or "tolerance" for corruption is the motivation behind its sustenance. 